\title{
Pengembangan Perpustakaan Digital Berbasis Web di Perpustakaan Jurusan Pendidikan Dasar Universitas Pendidikan Ganesha
}

\author{
Oleh \\ Kadek Surya Mahedy \\ Jurusan Manajemen Informatika, FTK, Undiksha
}

\begin{abstract}
Abstrak
Perpustakaan sebagai pemberi layanan kepada pemakai atau pengunjung memerlukan metode-metode pelayanan yang bersifat cepat, mudah dan efisien. Layanan perpustakaan yang masih bersifat manual menimbulkan berbagai kendala dalam pemberian layanan seperti layanan bersifat lambat, sulitnya pencarian koleksi dan kurang akuratnya data yang diarsip. Kemajuan teknologi informasi dan komputer menawarkan peluang sangat besar untuk menunjang kelancaran tugas-tugas di berbagai bidang kehidupan termasuk di dalamnya bidang perpustakaan. Perpustakaan sebagai institusi pengelola informasi merupakan salah satu bidang penerapan teknologi informasi yang berkembang dengan pesat. Salah satu fitur yang dapat dikembangkan dalam bidang perpustakaan adalah pengembangan perpustakaan digital berbasis web. Pemanfaatan web site memberi kemudahan akan akses informasi yang lebih cepat baik dari dalam maupun dari luar perpustakaan. Penelitian ini menghasilkan sebuah perangkat lunak perpustakaan digital berbasis web yang diharapkan menjadi alternatif pemberian layanan untuk mengatasi kendala-kendala dalam akses informasi di perpustakaan, proses pelayanan perpustakaan, dan pengarsipan data yang dilakukan secara manual. Sistem ini penggunaannya mudah, data yang disimpan akurat dan mudah dimutakhirkan, serta informasi data anggota dan koleksi perpustakaan dapat diakses kapan saja diperlukan melalui internet. Sistem ini dibangun dengan model website menggunakan script PHP dan database menggunakan My SQL.
\end{abstract}

Kata kunci : perpustakaan, perpustakaan digital, web.

\begin{abstract}
Library as a service to users or visitors requiring service methods that are fast, easy and efficient. Library services are still manually create many obstacles in the provision of services such as services are slow, difficult search and less accurate collection of data archived. The progress of information and computer technology offers tremendous opportunities to support the smooth running tasks in various fields of life including the library field. Library as an institution of information management is one field of application of information technology is growing rapidly. One
\end{abstract}


feature that can be developed in the library field is the development of web-based digital library. Utilization of the web site will provide easy access to information more quickly both from within and from outside the library. This research resulted in a software web-based digital library is expected to be an alternative delivery of services to overcome constraints in access to information in libraries, the library services, and data archiving done manually. This system uses easy, accurate data stored and easily updated, as well as members of data and information collection can be accessed whenever needed through the internet. This system was built with web site model using PHP scripts and databases using My SQL.

Keyword : library, digital library, web.

\section{Pendahuluan}

Perpustakaan sebagai institusi yang bertugas mengelola bahan pustaka, baik berupa buku maupun bukan berupa buku (non book material) sehingga dapat digunakan sebagai sumber informasi oleh setiap pemakainya. [Arif, 2003]. Perpustakaan sebagai pemberi layanan kepada pemakai atau pengunjung memerlukan metode-metode pelayanan yang bersifat cepat, mudah dan efisien. Layanan perpustakaan yang masih bersifat manual menimbulkan berbagai kendala dalam pemberian layanan seperti layanan bersifat lambat, sulitnya pencarian kolehsi dan kurang akuratnya data yang diarsip.

Kemajuan teknologi informasi dan komputer menawarkan peluang sangat besar untuk menunjang kelancaran tugas-tugas di berbagai bidang kehidupan termasuk di dalamnya bidang perpustakaan. Perpustakaan sebagai institusi pengelola informasi merupakan salah satu bidang penerapan teknologi informasi yang berkembang dengan pesat. Salah satu fitur yang dapat dikembangkan dalam bidang perpustakaan adalah pengembangan perpustakaan digital berbasis web. Pemanfaatan web site memberi kemudahan akan akses informasi yang lebih cepat baik dari dalam maupun dari luar perpustakaan.

Pengembangan perpustakaan digital berbasis web dipilih menjadi alternatif pemberian layanan mengingat pengguna layanan perpustakaan 
PGSD bukan hanya mahasiswa dari Kabupaten Buleleng tetapi juga berasal dari kabupaten yang lain. Mahasiswa yang ingin mengetahui informasi koleksi bahan pustaka yang dimiliki perpustakaan tidak harus datang ke perpustakaan karena dapat diakses melalui internet. Sehingga mahasiswa yang berasal dari luar daerah juga bisa memanfaatkan layanan perpustakaan. Perpustakaan digital berbasis web memberikan banyak keuntungan bagi perpustakaan diantaranya : penggunaannya mudah, data yang disimpan akurat dan mudah dimutakhirkan, serta informasi data anggota dan koleksi perpustakaan dapat diakses kapan saja diperlukan melalui internet. Keunggulan sistem ini adalah penggunaannya mudah, data yang disimpan akurat dan mudah dimutakhirkan, serta informasi data anggota dan koleksi perpustakaan dapat diakses kapan saja diperlukan melalui internet. Dari paparan di atas maka dipandang perlu untuk mengembangkan sebuah sistem infomasi perpustakaan digital yang berbasis web di perpustakaan PGSD.

Berdasarkan uraian pada latar belakang diatas, rumusan masalah dalam penelitian ini adalah 1) bagaimanakah rancangan perangkat lunak perpustakaan digital berbasis web? 2) bagaimanakah implementasi perangkat lunak perpustakaan digital berbasis web?

\section{Kajian Teori}

Sistem layanan yang dipakai di suatu perpustakaan adalah sistem terbuka dan sistem tertutup (Bafadal, 2005:125). Layanan perpustakaan yang sering dilakukan oleh setiap perpustakaan antara lain : Layanan Ruang Baca, Layanan Sirkulasi, dan Layanan Rujukan

Perpustakaan digital adalah suatu perpustakaan yang menyimpan data buku (tulisan) dalam bentuk file elektronik dan mendistribusikannya dengan menggunakan protokol elektronik melalui jaringan komputer. (www.ilmukomputer.com, Juli 2003). Pada sebuah perpustakaan digital terdapat beberapa komponen utama yang sangat penting, yaitu: Admin, 
Buku (Buku fisik dan Non Fisik), File, Pengguna Layanan, Sistem Peminjaman dan Pemesanan Buku Di Perpustakaan Digital, Sistem Download Di Perpustakaan Digital

HTML atau Hypertext Markup Language merupakan suatu bahasa pemrograman untuk membangun sebuah dokumen dalam bentuk halaman di web.

PHP merupakan salah satu bahasa pemrograman web yang paling dikenal saat ini. PHP adalah kependekan dari "PHP: Hypertext Preprocessor ".

Menurut Fathansyah (1999), basisdata merupakan kumpulan field/tabel/arsip yang saling berhubungan yang disimpan dalam media penyimpanan elektronis.

World Wide Web (WWW) atau yang lebih dikenal dengan nama web, merupakan salah satu layanan yang didapat oleh pemakai komputer yang terhubung ke internet.

\section{Metode dan Prosedur Penelitian}

Kegiatan penelitian ini merupakan pengembangan perangkat lunak, bukan penelitian eksperimen maupun penelitian tindakan. Sasaran akhir yang diharapkan adalah menghasilkan rancangan dan implementasi sistem Perpustakaan Digital Berbasis Web. Tempat pelaksanaan penelitian Perpustakaan Pendidikan Guru Sekolah Dasar (PGSD), sedangkan uji kelayakan sistem dilakukan di laboratorium komputer jurusan Manajemen Informatika Unversitas Pendidikan Ganesha. 




Gambar 1 Paradigma Prototyping

Pengembangan perangkat lunak sistem perpustakaan digital berbasis web ini mengikuti metodologi pengembangan perangkat lunak yaitu paradigma prototyping. Paradigma prototyping meliputi enam tahapan yaitu :

- Pengumpulan Kebutuhan dan Perbaikan

Pada tahap ini dilakukan pengumpulan kebutuhan perangkat lunak yang akan dibangun yang meliputi pendataan kebutuhan, data mana yang sudah tersedia, serta data mana yang perlu dikaji lebih jauh. Implementasi kegiatan pada tahap ini meliputi studi literatur, diskusi dan observasi.

- Desain Cepat

Hasil pada tahap pengumpulan kebutuhan kemudian dimanfaatkan sebagai data awal untuk mendesain spesifikasi global dari produk yang hendak dihasilkan. Tahap ini lebih terfokus pada aspek-aspek produk yang akan dimunculkan pada bagian tampilan.

- Membangun prototipe

Desain awal yang sudah dihasilkan selanjutnya diimplementasikan untuk mendapatkan simulasi dari hasil akhir yang diinginkan. Pekerjaan pada tahap ini belum menyentuh aspek detail dari produk 
yang dibangun dan lebih difokuskan untuk mempermudah pemahaman terhadap proses.

- Evaluasi prototipe

Tahap ini dilakukan validasi dari nara sumber yang relevan yakni : pakar perpustakaan (pustakawan) dan pakar bidang pemrograman. Koreksi dari dari komponen ini akan dijadikan dasar perbaikan sistem sehingga dapat dihasilkan produk yang lebih bagus.

- Perbaikan prototipe

Kekurangan-kekurangan yang didata dari hasil evaluasi terhadap desain cepat selanjutnya digunakan sebagai masukan untuk melakukan revisi pada desain cepat. Siklus yang meliputi desain cepat, membangun prototipe, evaluasi prototipe oleh pengguna, dan perbaikan prototipe kemungkinan berulang lebih dari sekali sampai diperoleh sistem yang sesuai.

- Rekayasa produk

Hasil desain cepat yang disepakati antara pengembangan dengan pengguna selanjutnya digunakan sebagai acuan dalam pengembangan perangkat lunak riil yang nantinya akan digunakan.

\section{Hasil dan Pembahasan}

Aplikasi Perpustakaan Digital Berbasis Web di Perpustakaan Jurusan PGSD ini memiliki dua pengguna sistem, yaitu admin dan user. Admin ialah orang yang dapat melakukan proses antara lain login, mengatur tampilan menu situs web dan menampilkan informasi di halaman utama situs web, melakukan proses input data buku, jenis buku, proses (input, edit, dan delete), melakukan proses pencarian data, memberi fasilitas download pada data buku dan data referensi tertentu. User atau pengguna biasa ialah orang yang hanya dapat melakukan proses dowload dan pencarian data yang ada.

Pada gambar 2 akan terlihat hubungan antara admin, anggota, pengguna biasa dan kebutuhan sistem dalam bentuk diagram use case. 


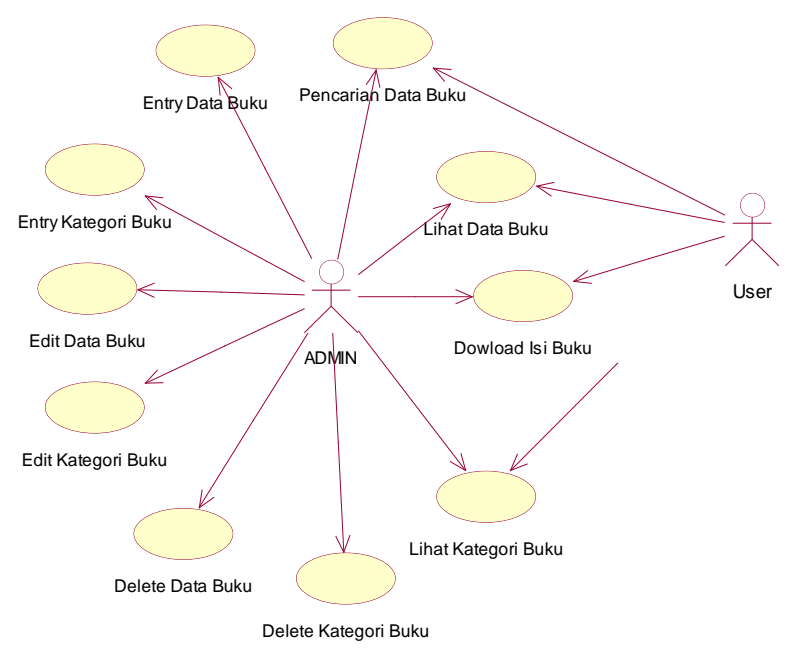

Gambar. 2 Diagram Use Case

Perangkat lunak perpustakaan digital berbasis web di perpustakaan jurusan PGSD diimplementasikan menggunakan PHP sebagai script untuk mengolah dan memproses data secara interaktif dan dinamis. MySql sebagai basis data server yang akan menyimpan semua data. Tampilan halaman depan sistem ditunjukkan pada gambar 3 . Halaman depan merupakan tampilan awal dari perpustakaan digital, pada bagian ini akan menampilkan koleksi buku terbaru, dan pada bagian menu terdapat beberapa fitur yaitu Buku Teks, Buku Ajar, Buku Kelas, Jurnal, Modul PJJ dan Lap PPL Mahasiswa. 


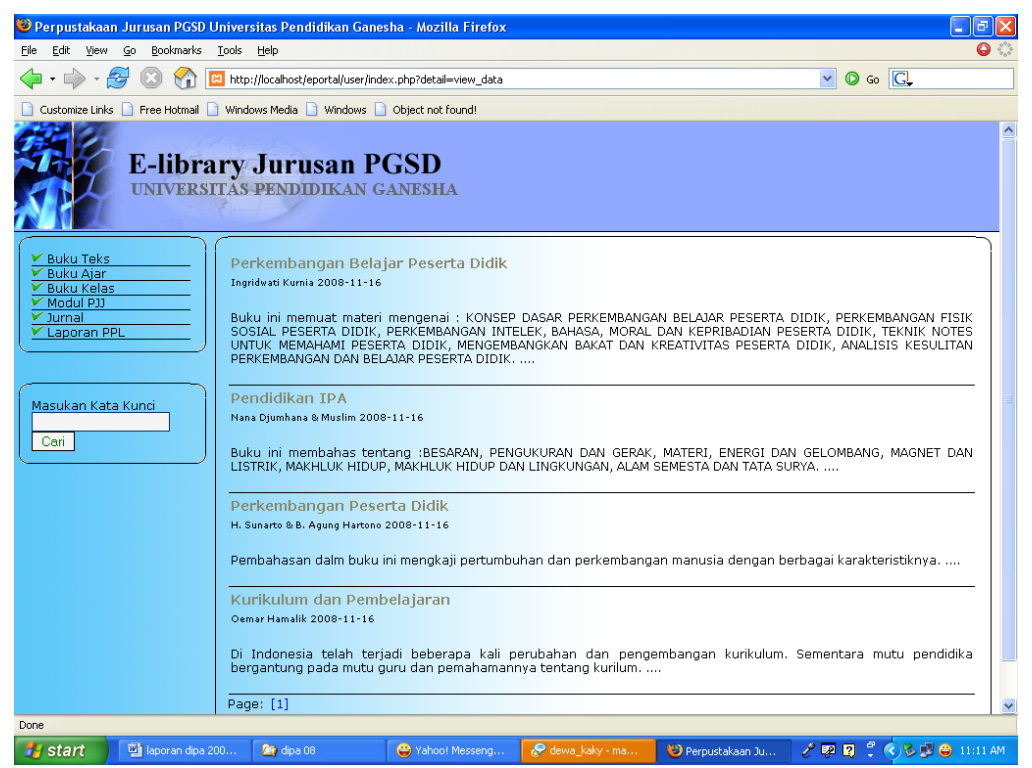

Gambar 3 Halaman Depan

Gambar 4 merupakan halaman pencarian Buku Teks, Buku Ajar, Buku Kelas, Jurnal, Modul PJJ dan Lap PPL Mahasiswa. User atau pengguna dapat melakukan proses pencarian data buku dengan memasukan key word atau kata kunci pencarian. User dapat melakukan proses pencarian berdasarkan judul buku, berdasarkan penyusun, dan berdasarkan, abstrak. 

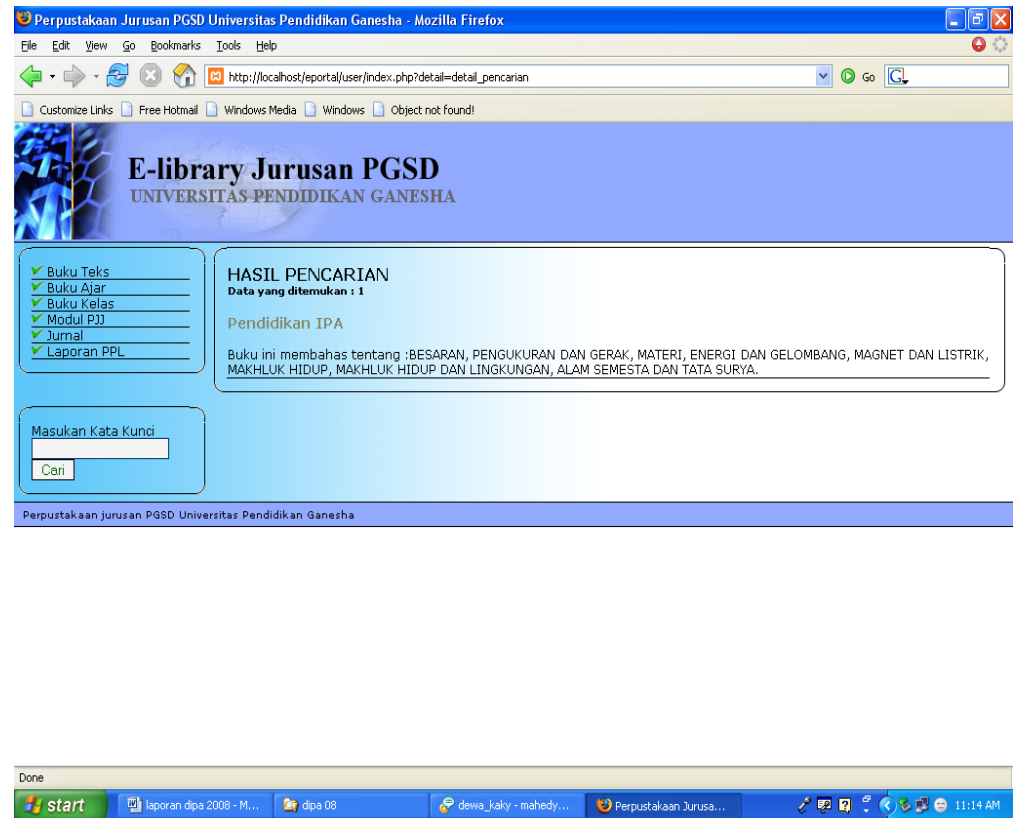

Gambar 4 Halaman Pencarian

Selain halaman untuk user juga disediakan halaman untuk admin yang tugasnya memasukkan data buku, memasukkan data anggota, dan mengupload file-file buku. Untuk masuk halaman admin harus memasukkan username dan password sehingga tidak semua orang bisa mengakses halaman ini, untuk detailnya terlihat seperti gambar 5 .
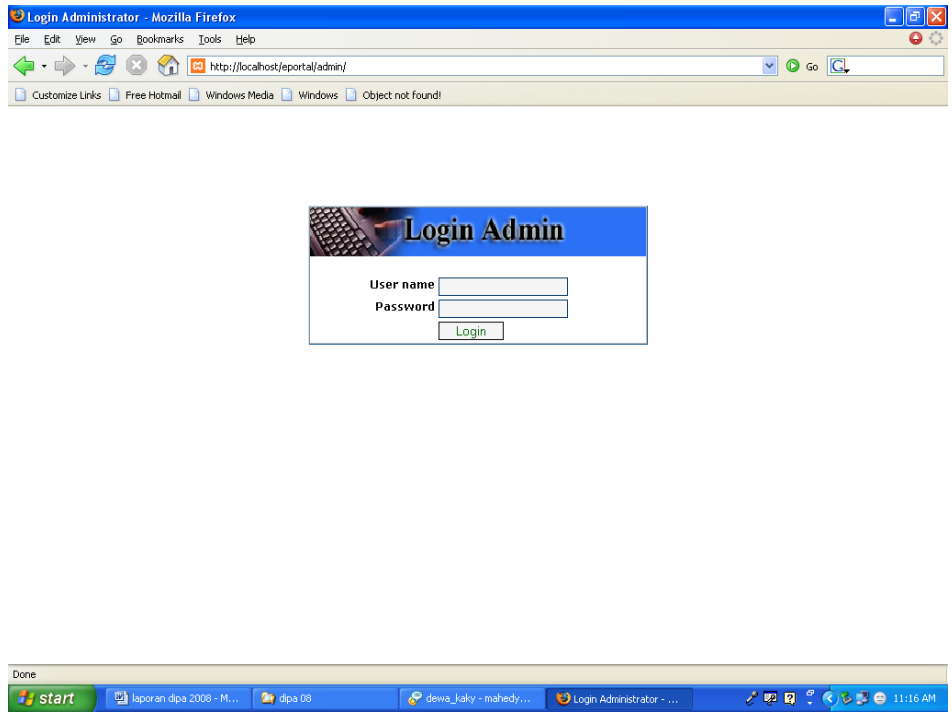

Gambar 5 Halaman Log in Admin

Pengembangan Perpustakaan Digital .(Kadek Surya Mahedy) 
Admin bisa memasukkan data buku pada halaman tambah buku. Data buku yang dimasukkan yaitu : ID buku, nama buku, kode ISBN, pengarang, penerbit, kategori, deskripsi/abstrak, tahun terbit, halaman buku, edisi, jumlah buku, sampul buku, asal buku, tercatat sejak, dan kondisi buku. Halaman tambah buku terlihat pada gambar 6 .

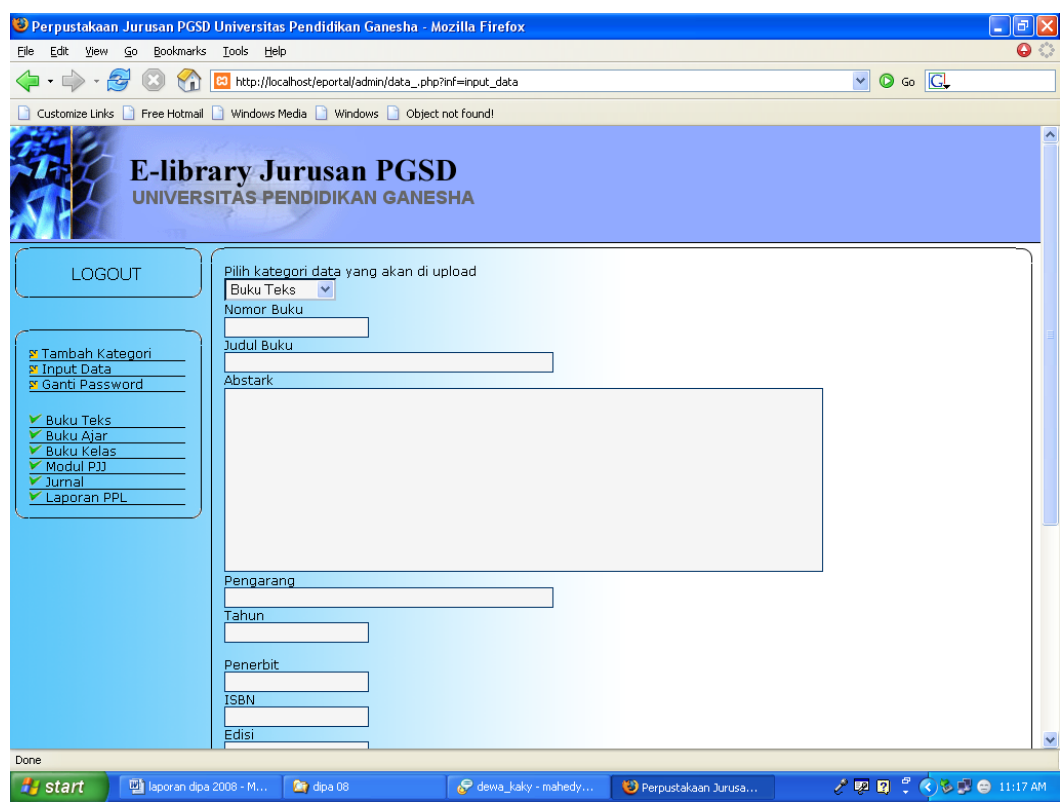

Gambar 6 Halaman tambah data

Admin juga dapat menambah jenis/kategori buku sesuai dengan kebutuhan perpustakaan pada halaman tambah kategori. Halaman tambah kategori terlihat pada gambar 7 . 

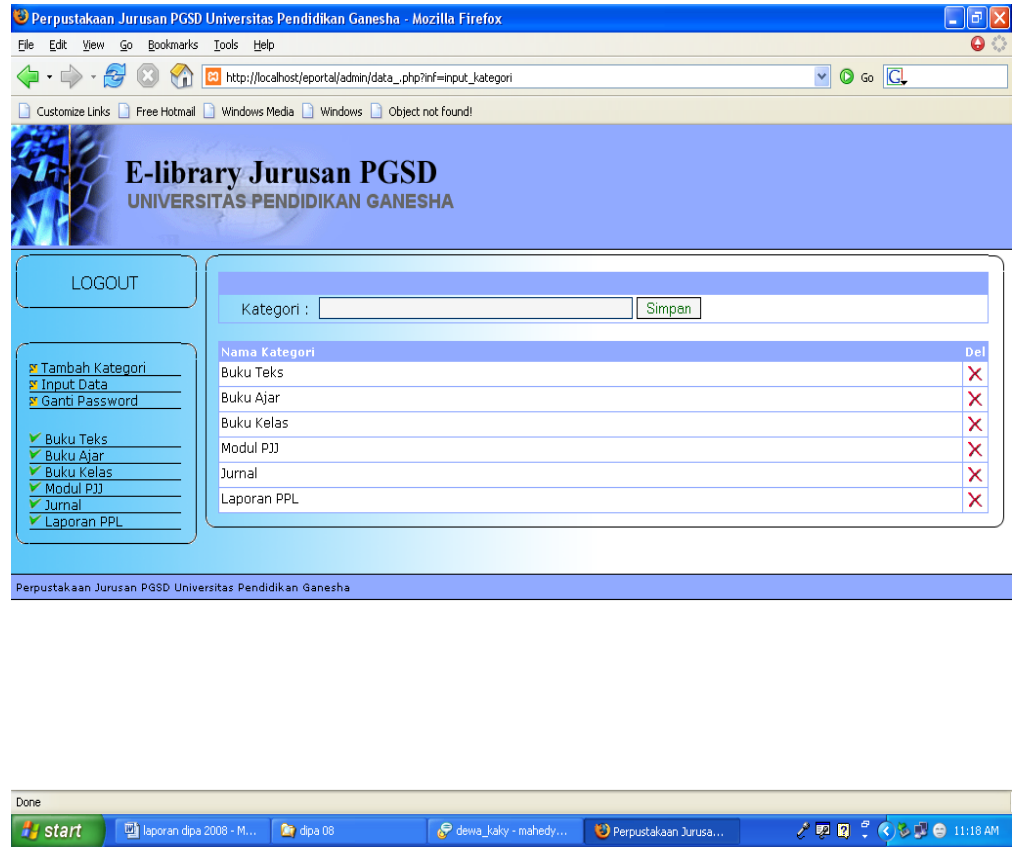

Gambar 7 Tambah Kategori

\section{Penutup}

Rancangan dan Pengembangan Perpustakaan Digital Berbasis Web di Perpustakaan Jurusan PGSD adalah sebagai salah satu media informasi yang dapat memberikan kemudahan dalam proses penginputan, pengeditan, penghapusan, dan pencarian data-data yang ada di perpustakaan seperti buku-buku maupun referensi-referensi, buku ajar, modul jurnal dan laporan PPL mahasiswa. Rancangan dan pengembangan perpustakaan digital berbasis web ini diimplementasikan dengan menggunakan PHP sebagai script untuk mengolah dan memproses data secara interaktif dan dinamis. $M y S q l$ sebagai basis data server yang akan menyimpan semua data.

Rancangan dan pengembangan perpustakaan digital berbasis web ini dibangun dengan harapan agar para mahasiswa dan dosen dapat lebih mudah dalam pencarian data. Selain itu pegawai juga dapat lebih mudah dalam pengelolaan data yang berhubungan dengan perpustakaan. 


\section{DAFTAR PUSTAKA}

Artana I Ketut. 2006. Menjadikan Perpustakaan Rumah Belajar. Warta UNDIKSHA. 01/Tahun 1/Januari-Maret 2006.

Bafadal Ibrahim. 2005. Pengelolaan Perpustakaan Sekolah. Jakarta. Bumi Aksara.

Fathansyah. 1999. Basis Data. Bandung. CV. Informatika.

Indrajit, Richardus Eko, 2000. Pengantar Konsep Dasar Manajemen Informasi dan Teknologi Informasi. Elex Media Komputindo. Jakarta.

Nugroho Bunafit. 2004. Perancangan Web dengan Fireworks dan Dreamweaver MX. Gava Media:Yogyakarta.

Arif, Ikhwan. 2003. Konsep dan Perencanaan dalam Automasi Perpustakaan.

www.lib.ugm.ac.id/data/download/1073443876_MakalahAP.do c Diakses tanggal 9 Juli 2007

Saiful I, Huda. 2007. Automasi Perpustakaan. www.media.diknas.go.id/media/document/4565.pdf. Diakses tanggal 9 Juli 2007

Yudha Yudhanto. 2007. Menggagas Perpustakaan Digital. www.ilmukomputer.com Diakses tanggal 10 Juli 2008 